\title{
Biomass production in experimental grasslands of different species richness during three years of climate warming
}

\author{
H. J. De Boeck ${ }^{1}$, C. M. H. M. Lemmens ${ }^{1}$, C. Zavalloni ${ }^{1}$, B. Gielen ${ }^{1}$, S. Malchair ${ }^{3}$, M. Carnol ${ }^{3}$, R. Merckx ${ }^{2}$, \\ J. Van den Berge ${ }^{1}$, R. Ceulemans ${ }^{1}$, and I. Nijs ${ }^{1}$ \\ ${ }^{1}$ Research Group of Plant and Vegetation Ecology, Department of Biology, Universiteit Antwerpen (Campus Drie Eiken), \\ Universiteitsplein 1, B-2610 Wilrijk, Belgium \\ ${ }^{2}$ Division Soil and Water Management, Faculty of Bioscience Engineering, Katholieke Universiteit Leuven, Kasteelpark \\ Arenberg 20, B-3001 Leuven/Heverlee, Belgium \\ ${ }^{3}$ Lab. of Plant and Microbial Ecology, Institute of Plant Biology B22, Univ. of Liège, Sart Tilman, B-4000 Liège, Belgium
}

Received: 19 November 2007 - Published in Biogeosciences Discuss.: 13 December 2007

Revised: 26 March 2008 - Accepted: 2 April 2008 - Published: 21 April 2008

\begin{abstract}
Here we report on the single and combined impacts of climate warming and species richness on the biomass production in experimental grassland communities. Projections of a future warmer climate have stimulated studies on the response of terrestrial ecosystems to this global change. Experiments have likewise addressed the importance of species numbers for ecosystem functioning. There is, however, little knowledge on the interplay between warming and species richness. During three years, we grew experimental plant communities containing one, three or nine grassland species in 12 sunlit, climate-controlled chambers in Wilrijk, Belgium. Half of these chambers were exposed to ambient air temperatures (unheated), while the other half were warmed by $3^{\circ} \mathrm{C}$ (heated). Equal amounts of water were added to heated and unheated communities, so that warming would imply drier soils if evapotranspiration was higher. Biomass production was decreased due to warming, both aboveground $(-29 \%)$ and belowground $(-25 \%)$, as negative impacts of increased heat and drought stress in summer prevailed. Complementarity effects, likely mostly through both increased aboveground spatial complementarity and facilitative effects of legumes, led to higher shoot and root biomass in multi-species communities, regardless of the induced warming. Surprisingly, warming suppressed productivity the most in 9-species communities, which may be attributed to negative impacts of intense interspecific competi-
\end{abstract}

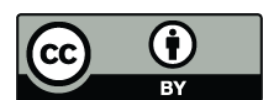

Correspondence to: H. J. De Boeck (hans.deboeck@ua.ac.be) tion for resources under conditions of high abiotic stress. Our results suggest that warming and the associated soil drying could reduce primary production in many temperate grasslands, and that this will not necessarily be mitigated by efforts to maintain or increase species richness.

\section{Introduction}

As supported by a growing body of observations, the global climate is changing rapidly (IPCC, 2007). Global surface temperatures are projected to increase with 1.8 to $4.0^{\circ} \mathrm{C}$ by 2100 ("best estimates"), in reaction to rising atmospheric concentrations of greenhouse gases. A number of studies have addressed how plant communities will react to a warmer world, finding numerous possible responses to higher temperatures. Stimulation of primary productivity is possible mainly through altered reaction kinetics (Larcher, 2003), lengthening of the growing season (Myneni et al., 1997; Walther, 2003), and improved access to nutrients (Rustad et al., 2001). Adverse effects of climate warming on the productivity of plant communities could, among others, be caused by increased temperature stress (White et al., 2000), water shortage as a result of increased evapotranspiration (ET) (Saleska et al., 1999), and in the long term by a decrease of species richness (S). The issue of declining species numbers has a number of (anthropogenic) causes (Sala et al., 2000), and climate change is but one of these (Klein et al., 2004). Community productivity is generally lower when fewer species are present, both in artificially assembled

Published by Copernicus Publications on behalf of the European Geosciences Union. 
(Hector et al., 1999; Hooper et al., 2005) and in natural communities (Gillman and Wright, 2006). Two widely debated mechanisms are thought to be involved in altering the community performance in response to changing species numbers (Hector et al., 2000; Huston et al., 2000). The first is complementarity (including facilitation), which allows for more of the total amount of available resources to be taken up by the community if more species are present. When $\mathrm{S}$ is higher, there is also a higher probability for a community to contain one or more productive species that dominate this community. This is the "selection effect", a pure probability effect, occurring in both artificially assembled and natural communities (see Hooper et al., 2005 for a review). This implies that higher biomass in species-rich communities can arise from only a few (dominant) species. Complementarity and the selection effect can operate simultaneously, and are separated using the method of additive partitioning (Loreau and Hector, 2001). Roscher et al. (2005) provided experimental evidence that the positive relationships between plant species richness and biomass production are robust, and independent of spatial scale or species pools. It could be expected that species-rich communities are better "equipped" to face negative aspects of climate warming. Higher temperatures would lower the soil water content (unless precipitation increases), which could reinforce the importance of complementarity for water. Furthermore, multi-species communities have a larger probability of containing species better adapted to warming and/or drought, and would therefore be better "insured" than species-poor systems (Naeem and $\mathrm{Li}, 1997)$. On the other hand, if enhanced productivity in species-rich communities increases canopy transpiration, then soil drying may occur earlier, which would counteract the productivity enhancement (Pfisterer and Schmid, 2002). As drought would already be more frequent and severe if ambient temperatures were higher, such a reduction of the positive effect of $\mathrm{S}$ on productivity could be more pronounced under heating. The multitude of possible mechanisms regarding the interplay of ecosystem stability and biodiversity is mirrored by the differing conclusions in experimental studies on this topic, with both positive (e.g. Kahmen et al., 2005) and negative (e.g. Van Peer et al., 2004) effects of species richness on ecosystem stability reported.

To uncover both single-factor and interactive effects of climate warming and species richness, we subjected artificially assembled grassland communities of different species richness levels to either ambient temperatures or temperatures that were continuously $3^{\circ} \mathrm{C}$ higher. Precipitation was identical in the unheated and the heated communities to ensure that warming would also encompass lower soil water contents if ET was higher. The current study investigates biomass production both above- and belowground, and how this is affected by warming and species richness over the course of three years. Including root biomass is of significant importance, as root:shoot ratios could increase in response to climate warming and dryer soils (Chaves et al., 2002). We pos- tulate the following questions: (1) is grassland biomass production positively or negatively affected by warming, (2) is productivity higher in multi-species communities, and how important are complementarity and selection effects, and (3) are there interactions between the two global change factors under consideration? In an earlier study (De Boeck et al., 2007a), we reported on productivity in the same communities during the first four months following planting. The results suggested decreased productivity through warming, slightly increased productivity in multi-species systems, and hinted of interaction between the two treatments. The current study investigates whether these effects were merely shortterm responses, as such transient effects have been found in other treatment studies (e.g. Calfapietra et al., 2003), or whether they were persistent or gained in importance during three years. Importantly, the substantial knowledge gained through process-based studies in the same experimental platform, i.e. on autumn physiology (Gielen et al., 2005), water use (De Boeck et al., 2006a), photochemistry (Gielen et al., 2007) and $\mathrm{CO}_{2}$ fluxes (De Boeck et al., 2007b) enables us to causally explain observed productivity responses.

\section{Material and methods}

\subsection{Study site and experimental set-up}

This study was conducted at the Drie Eiken Campus of the University of Antwerp (Belgium, $51^{\circ} 09^{\prime} \mathrm{N}, 4^{\circ} 24^{\prime} \mathrm{E}$ ), where an experimental platform containing 288 artificially assembled grassland model ecosystems in containers was established in 2003. The climate of north Belgium is characterized by mild winters and cool summers, with an average annual air temperature of $9.6^{\circ} \mathrm{C}$, and mean monthly air temperatures between $2.2^{\circ} \mathrm{C}$ (January) and $17.0^{\circ} \mathrm{C}$ (July). Annual precipitation averages $776 \mathrm{~mm}$, equally distributed throughout the year.

At the start of the experiment (2003), the platform consisted of 12 sunlit, climate-controlled chambers $\left(2.25 \mathrm{~m}^{2}\right.$ ground area) facing south, half at ambient temperatures (unheated) and the other half continuously at ambient temperatures $+3^{\circ} \mathrm{C}$ (heated). Each year in November, two chambers were removed for destructive harvesting and root analysis. Each chamber had an individual air control group with an electrical heating battery, and was linked to a central refrigeration unit by isolated pipes. The conditioned air was evenly distributed throughout the chambers by means of aerators with regulated flow. The aluminium-frame chambers were covered with a colourless polycarbonate plate ( $4 \mathrm{~mm}$ thick), and polyethylene film (200 $\mu \mathrm{m}$ thick) at the sides, both UV transparent and with a total light transmission of $86 \%$.

Each chamber (the blocking variable in the statistical analyses) contained the same series of 24 different grassland communities of varying species richness: nine monocultures, nine $S=3$ communities and six $S=9$ communities. 
Table 1. Results of the PROC MIXED analysis on aboveground biomass production and complementarity and selection effects in all periods (see text for details). Significance (sgn) of effects of temperature treatment $(T)$, species richness $(\mathrm{S})$, period, and their interactions $(\times)$ are indicated as ns, not significant; $* P<0.05$; ** $P<0.01$; *** $P<0.001 . F$-values, enumerator (ndf) and denominator (ddf) degrees of freedom are also shown.

\begin{tabular}{lccccccccccccc}
\hline & \multicolumn{3}{c}{ aboveground biomass } & \multicolumn{3}{c}{ complementarity } & \multicolumn{3}{c}{ selection effect } \\
\hline & ndf & ddf & F & sgn & ndf & ddf & F & sgn & ndf & ddf & F & sgn \\
\hline $\mathrm{T}$ & 1 & 10 & 548 & $* * *$ & 1 & 4 & 2.7 & ns & 1 & 4 & 0.1 & ns \\
$\mathrm{S}$ & 2 & 20 & 49.1 & $* * *$ & 1 & 4 & 0.1 & $\mathrm{~ns}$ & 1 & 4 & 1.0 & $\mathrm{~ns}$ \\
Period & 4 & 28 & 11.1 & $* * *$ & 4 & 4 & 3.5 & $\mathrm{~ns}$ & 4 & 4 & 1.3 & $\mathrm{~ns}$ \\
$\mathrm{~T} \times \mathrm{S}$ & 2 & 20 & 3.3 & $*$ & 1 & 4 & 1.3 & $\mathrm{~ns}$ & 1 & 4 & 1.5 & $\mathrm{~ns}$ \\
$\mathrm{~T} \times$ Period & 4 & 28 & 1.2 & $\mathrm{~ns}$ & 4 & 4 & 0.4 & $\mathrm{~ns}$ & 4 & 4 & 1.0 & $\mathrm{~ns}$ \\
$\mathrm{~S} \times$ Period & 8 & 56 & 2.2 & $*$ & 4 & 4 & 2.1 & $\mathrm{~ns}$ & 4 & 4 & 0.7 & $\mathrm{~ns}$ \\
$\mathrm{~T} \times \mathrm{S} \times$ Period & 8 & 56 & 0.4 & $\mathrm{~ns}$ & 4 & 4 & 1.3 & $\mathrm{~ns}$ & 4 & 4 & 0.7 & $\mathrm{~ns}$ \\
\hline
\end{tabular}

These communities are the experimental unit in this study, and were placed in PVC containers $(24 \mathrm{~cm}$ inner diameter, $60 \mathrm{~cm}$ deep) installed in the soil. Each community contained 30 individuals planted in a hexagonal grid at $4 \mathrm{~cm}$ distance, with interspecific interactions maximised. Similar plant densities were used in other experiments (e.g. Van Peer et al., 2004), and are deemed realistic for temperate grasslands. Prior to planting in the containers in June 2003 (which took approximately three weeks), the plants were sown in small seedling pots in April 2003. We opted for species from three functional groups, which were equally represented at each S level: three grass species (Dactylis glomerata L., Festuca arundinacea Schreb., Lolium perenne L.), three $\mathrm{N}$-fixing dicots (Trifolium repens L., Medicago sativa L., Lotus corniculatus L.), and three non- $\mathrm{N}$-fixing dicots (Bellis perennis L., Rumex acetosa L., Plantago lanceolata L.). These C3 species comply with three criteria: presence in European temperate grasslands, perennial life cycle, and preference for clay or loam soil. In addition, they represented different productivities, and different temperature and drought resistances. Species representative of the three functional groups were used to create each of the $S=3$ communities, with each species combined only once with any other species. Out of the three possible sets of nine different $S=3$ communities that met these criteria, one randomly chosen set was used. Each of the six $\mathrm{S}=9$ communities had a different internal arrangement, to ensure that each species interacted to the same extent with any other species over the totality of the six $S=9$ communities.

The soil used in the experiment $(76.3 \%$ silt, $14.8 \%$ clay and $8.7 \%$ sand; field capacity $0.39 \mathrm{~m}^{3} \mathrm{~m}^{-3}$; $\mathrm{pH} 6.45$, carbon content $1.6 \%$ ) was collected from an agricultural field and sieved $(0.5 \mathrm{~mm}$ mesh size) to remove stones and large organic material. No fertiliser was added to this rich agricultural soil. Plants were treated regularly to avoid fungal infection and insect damage, and weeding was done manually throughout the experiment. Watering was done in accordance with actual outside conditions, and was equal in both temperature treatments so that soil water content would be lower if warming increased evapotranspiration. Further information regarding the experimental set-up and watering regime can be found in De Boeck et al., 2006a and 2007a.

\subsection{Measurements}

Aboveground biomass $\left(B_{\text {shoot }}\right)$ was determined by cutting plants $3.5 \mathrm{~cm}$ above the soil surface in all containers. Such harvests were carried out in five periods: late October 2003, 2004 and 2005, early June 2004 and late May 2005. Of half of the heated and unheated chambers, biomass was collected per species within community, while the biomass of the other chambers was collected per community. Plant material was then oven dried (one week at $70^{\circ} \mathrm{C}$ ) and weighed. Two chambers (one heated and one unheated) were dismantled each year early November, the stubble biomass (biomass of the lowest $3.5 \mathrm{~cm}$ aboveground, $B_{\text {stubble}}$ ) was harvested, and all plant containers were removed. Soil slices $(4 \mathrm{~cm}$ thick) were subsequently cut out of the soil cylinder at depths of $1-5 \mathrm{~cm}, 6-10 \mathrm{~cm}, 13-17 \mathrm{~cm}, 23-27 \mathrm{~cm}, 35-39 \mathrm{~cm}$ and $48-$ $52 \mathrm{~cm}$. These soil samples were subsequently dried during two weeks at $70^{\circ} \mathrm{C}$ to prevent root decomposition. Later, roots were manually washed from the soil slices, dried at $70^{\circ} \mathrm{C}$ and weighed.

Belowground biomass $\left(B_{\text {root }}\right)$ was reconstructed from the slice biomass by regression (the curve chosen per community to best fit the root distribution), followed by a calculation of root biomass for every $\mathrm{mm}$ along the depth profile and subsequent summation of these 1-mm biomass values. The root biomass in each layer compared to the total in all layers, provides an estimate of the distribution of roots throughout the soil. Root/shoot (R/S) ratios were calculated from $B_{\text {root }}$ and combined $B_{\text {shoot }}$ and $B_{\text {stubble }}$ in the subsequently dismantled chambers. Selection and complementarity effects were calculated for those chambers in which aboveground biomass was determined up to the species level, using the additive partitioning method formulated by Loreau and Hector (2001). By comparing the observed biomass production in mixtures with the expected production (based on 
Table 2. Results of one-sample t-tests (test value $=0$ ) on data of complementarity and selection in five different periods: (1) JuneOctober 2003, (2) November 2003-June 2004, (3) June-October 2004, (4) November 2004-May 2005, (5) June-October 2005. Data of 3- and 9-species communities and both temperature treatments were combined, as the mixed analysis on the whole dataset showed that neither of these factors had significant effects (see text). Significant $p$-values $(p<0.05)$ are indicated in bold and averages are expressed as $g$ community $^{-1}$ with overyielding $>0$ and underyielding $<0$.

\begin{tabular}{cccrc}
\hline & \multicolumn{2}{c}{ complementarity } & \multicolumn{2}{c}{ selection } \\
\hline period & average & $p$-value & average & $p$-value \\
\hline 1 & 2.41 & 0.056 & -0.05 & 0.917 \\
2 & 11.49 & 0.000 & 5.00 & 0.001 \\
3 & 16.59 & 0.000 & -2.24 & 0.256 \\
4 & 11.72 & 0.000 & -4.89 & 0.270 \\
5 & 14.90 & 0.003 & -2.21 & 0.672 \\
\hline
\end{tabular}

the monoculture productivity of each species in the mixture), we were able to calculate over - or underyielding and how complementarity and selection contributed to this.

\subsection{Statistical analysis}

Data were analysed using PROC MIXED in SAS (version 9.1, SAS Institute Inc., Cary, NC, USA) based on a splitplot design with the whole plot completely randomized (Littell et al., 2006). Temperature treatment was treated as the main factor and S-level was treated as a subfactor. When treatment effects or interactions were significant, means were separated using a posteriori Least-Squares means tests, with Bonferroni corrections for multiple comparisons. Such an analysis was, however, not possible for data related to root and stubble biomass, as no true replicates were available for these destructive measurements (see Sect. 2.2). Indicative tests were performed on these data instead, also using the PROC MIXED procedure, but this time considering the communities rather than the chambers as replicates within the temperature treatment. To test whether complementarity or selection was significantly different from 0 , we used onesample t-tests. All data were tested for normality with the Shapiro-Wilk statistic, and were square root transformed if not normally distributed. The significance level for all tests was 0.05 .

\section{Results}

\subsection{Biomass production}

Grassland communities growing at elevated temperatures for three growing seasons, produced significantly less biomass aboveground (Fig. 1), with productivity being reduced by
$29 \%$ aboveground $(p<0.001)$. Reductions were consistently observed throughout the course of the study, with no significant period $\times$ temperature treatment interaction. Our indicative test showed that the $25 \%$ average reduction in belowground biomass under warmer conditions (Fig. 1) could also be regarded as significant $(p<0.05)$. Productivity was generally stimulated by $\mathrm{S}$, both above $-(p<0.001)$ and belowground $(p<0.005$, indicative test). A significant period $\times \mathrm{S}$ interaction aboveground $(p<0.05)$ likely reflects the difference between the first and consecutive periods (Fig. 1a). An interactive effect between species richness and temperature treatment could only be analysed aboveground, and proved to be significant $(p<0.05)$ although a similar trend towards increased differences in biomass production at $\mathrm{S}=9$ between the two temperature treatments can be seen belowground (Fig. 1b).

\subsection{Complementarity and selection}

Differences in aboveground production between $\mathrm{S}=3$ and $\mathrm{S}=9$ were generally small and non-significant (LS means). In line with this result, we found that neither complementarity nor (net) selection differed significantly between these two richness levels. The net effect of selection did not change as a result of warming, as was also generally the case for complementarity (Fig. 2). Because the period-effect was on the verge of significance $(p<0.10)$, we performed one-sample ttests to detect significant deviations of complementarity or selection from zero for each period separately. Complementarity proved positive in 4 out of 5 cases (and nearly significant in the first period), while selection had no effects, with the exception of one period in which it stimulated productivity (Table 2). Although no significant interaction was found between $\mathrm{S}$ and temperature treatment, data were consistent with biomass data, with the largest differences between heated and unheated communities at $S=9$.

\subsection{Root distribution}

Root biomass was highest near the soil surface, with $48 \%$ of the roots located in the $1-5 \mathrm{~cm}$ layer, and gradually declined with increasing depth in the soil $(p<0.001$, indicative test). The same general pattern was found in all years, but in the last year, less roots were found near the soil surface (39\% in the $1-5 \mathrm{~cm}$ layer) versus more deeper down when compared with the other two years. No effects of either warming or $S$ were detected, but the significant interaction between species richness and depth $(p<0.005$, indicative test) indicates that the root distribution pattern was influenced by $S$, although differences were small (Fig. 3). Differences in root distribution between individual species were small and statistically undetectable. 


\section{A}
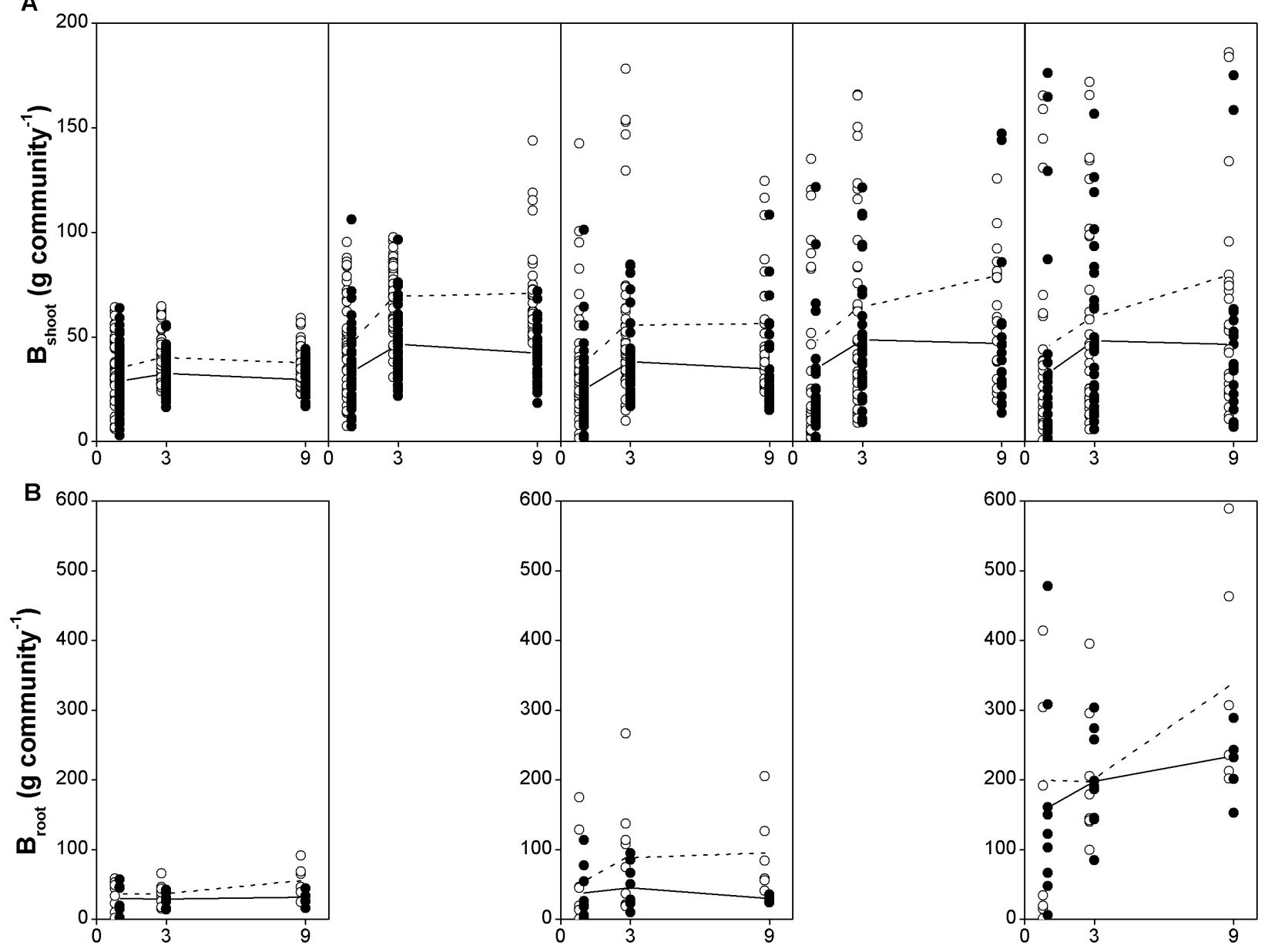

S

Fig. 1. Community biomass production - A - aboveground ( $>3.5 \mathrm{~cm}$ above the soil surface, $B_{\text {shoot }}$ ) in five consecutive periods (panels from left to right: June-October 2003, November 2003-June 2004, June-October 2004, November 2004-May 2005, June-October 2005) and - B - belowground $\left(B_{\text {root }}\right)$ in three consecutive years (panels from left to right: November 2003, November 2004, November 2005), at ambient temperatures (o) and ambient temperatures $+3^{\circ} \mathrm{C}(\bullet)$. Each symbol represents a different community, and 9 out of 1113 symbols for $B_{\text {shoot }}$, and 1 out of 144 symbols for $B_{\text {root }}$ are not depicted because their values exceed the Y-axis range deemed the limit for preserving clarity. Averages for unheated (- - ) and heated (-) communities are connected with a straight line. Symbols are slightly shifted with respect to the $X$-axis for clarity.

\subsection{Root/shoot ratio}

Neither warming nor species richness affected the ratio belowground versus aboveground biomass. This $\mathrm{R} / \mathrm{S}$ ratio increased sharply from 0.8 in the start-up year to 3.5 in the third year (with the year influence being significant; $p<0.001$, indicative test), in line with a much higher $B_{\text {root }}$ observed in year three (Fig. 1b). It is remarkable that, when comparing $B_{\text {shoot }}$ with $B_{\text {stubble, }}$, an effect of temperature treatment $(p<0.05$, indicative test $)$ and a temperature treatment $\times$ year interaction $(p<0.005$, indicative test) was found. This reflected a strong increase in stubble biomass and stubble versus aboveground biomass in the heated communities in the third year (Fig. 4). No effects of S were detected here.

\section{Discussion}

4.1 Is grassland biomass production positively or negatively affected by warming?

Exposing experimental grassland communities to a warmer climate resulted in a substantially lower biomass production, both above- and belowground. The decrease in aboveground productivity was consistently observed in all periods, which negates the possibility of a transient response, at least in the medium term. A positive effect of warming recorded on the same communities by Gielen et al. (2005), was an increased efficiency of the electron transport chain. However, the same study detected no warming-induced delay of 
Table 3. Overview of community scale parameters. Soil water content (SWC), evapotranspiration (ET) and water use efficiency (WUE): averages for each species richness (S) level and per temperature treatment, from August 2003 until October 2004 (see De Boeck et al., $2006 \mathrm{a}$ for details); net $\mathrm{CO}_{2}$ flux: averages from November 2003 until October 2005 (see De Boeck et al., 2007b for details).

\begin{tabular}{|c|c|c|c|c|c|c|c|c|}
\hline \multirow[b]{2}{*}{$S$} & \multicolumn{2}{|c|}{$\operatorname{SWC}(\%)$} & \multicolumn{2}{|c|}{$\operatorname{ET}\left(\mathrm{L} \mathrm{m}^{-2}\right.$ day $\left.^{-1}\right)$} & \multicolumn{2}{|c|}{ WUE (g biomass $\mathrm{L}^{-1}$ water) } & \multicolumn{2}{|c|}{ Net $\mathrm{CO}_{2}$ flux $\left(\mathrm{mol} \mathrm{m}^{-2}\right.$ year $\left.^{-1}\right)$} \\
\hline & unheated & heated & unheated & heated & unheated & heated & unheated & heated \\
\hline 1 & 28.7 & 27.2 & 3.05 & 3.20 & 1.85 & 1.33 & -63.6 & -64.0 \\
\hline 3 & 26.5 & 25.4 & 3.18 & 3.30 & 2.41 & 1.74 & -77.1 & -44.3 \\
\hline 9 & 26.6 & 25.2 & 3.17 & 3.28 & 2.53 & 1.59 & -59.0 & -33.1 \\
\hline average & 27.3 & 25.9 & 3.13 & 3.26 & 2.26 & 1.56 & -66.6 & -47.1 \\
\hline
\end{tabular}

senescence at the end of the growing season, while (unpublished) data of spring growth likewise do not show substantial earlier growth. This suggests that any production-enhancing effects of a lengthening of the growing season were small. In contrast, several negative effects of heating were recorded.

Lower soil moisture levels recorded in warmed communities (Table 3) triggered a decrease in stomatal conductance (Lemmens et al., 2006) ensuring that transpirative losses were dampened (De Boeck et al., 2006a). The decreased stomatal conductance contributed to lower photosynthetic rates, while plant respiration was also decreased, but by a lower amount (De Boeck et al., 2007b; net $\mathrm{CO}_{2}$ flux averages are shown in Table 3). This subsequently resulted in the decrease of biomass production reported here. Our study on carbon fluxes on these same communities revealed that the adverse effects of warming were concentrated and likely confined to late spring and summer (De Boeck et al., 2007b). Apart from indirect effects of (summer) drought, direct negative effects of increased temperatures were also found, with summer fluorescence measurements indicating an increased intensity of midday stress as a result of heating, causing down-regulation of photosystem 2 (Gielen et al., 2007). Such direct temperature effects may have been of lower importance, as a study on the European heat wave in the summer of 2003 suggested that most of the adverse effects on productivity were caused by drought stress (Reichstein et al., 2007).

Although plants can invest in expanding their root system to increase water uptake (Chaves, 2002), leading to an increase in $\mathrm{R} / \mathrm{S}$, we found no evidence of such increases, and the distribution of roots also remained unchanged under heating. Although the absence of a groundwater table and the container size $(60 \mathrm{~cm}$ depth) likely limited the extra quantities of water that could be extracted from the soil through root proliferation, this was probably not the only factor to have counteracted drought-induced R/S increases. Indeed, Edwards et al. (2004) reported that warming itself, without soil drying, had a negative effect on root biomass in temperate grasslands through increased root death. The root system in both temperature treatments became more extensive as the communities matured, with R/S values well above
1 , in accordance with other studies on temperate grasslands (Mokany et al., 2006). The markedly higher stubble versus aboveground biomass under heating in year three highlights that especially the amount of photosynthetic tissue, which is mostly located higher than $3.5 \mathrm{~cm}$ above the soil surface, was reduced by heating. The amount of data is, however, too limited to confidently ascribe this to a drought-avoidance strategy.

Changes in precipitation are one of the least certain aspects of climate change (IPCC, 2007). In line with other reports (Eatherall, 1997; De Valpine and Harte, 2001), this study suggests that unless precipitation increases, the productivity of many grasslands could significantly decline under climate warming. Indeed, grassland productivity is often limited by precipitation (Weltzin et al., 2003; Nippert et al., 2006). However, if productivity is limited primarily by low temperatures or low nutrient concentrations, such as in polar and alpine regions, warming may be beneficial through alleviation of these constraints either directly through higher temperatures or indirectly via increased nutrient mineralization rates (Riedo et al., 2001; Rustad et al., 2001; Aerts et al., 2006). In precipitation-limited grasslands, we expect considerable variation in productivity changes in the next decades, depending on future local precipitation regimes, although it is possible that drought-effects will be alleviated by rising atmospheric $\mathrm{CO}_{2}$ concentrations (Norby and Luo, 2004).

\section{Is productivity higher in multi-species communities, and how important are complementarity and selec- tion?}

More biomass was produced in mixtures than in monocultures, in line with similar experimental studies (Hector et al., 1999; van Ruijven and Berendse, 2005), while productivity differences between 3- and 9-species were small or absent as predicted from theory (De Boeck et al., 2006b). As expected (De Boeck et al., 2007a), S effects were smallest in the first growing season, as plant-plant interactions generally grow stronger in time (van Ruijven and Berendse, 2005). The method of additive partitioning revealed that the increase in productivity from monocultures to multi-species 


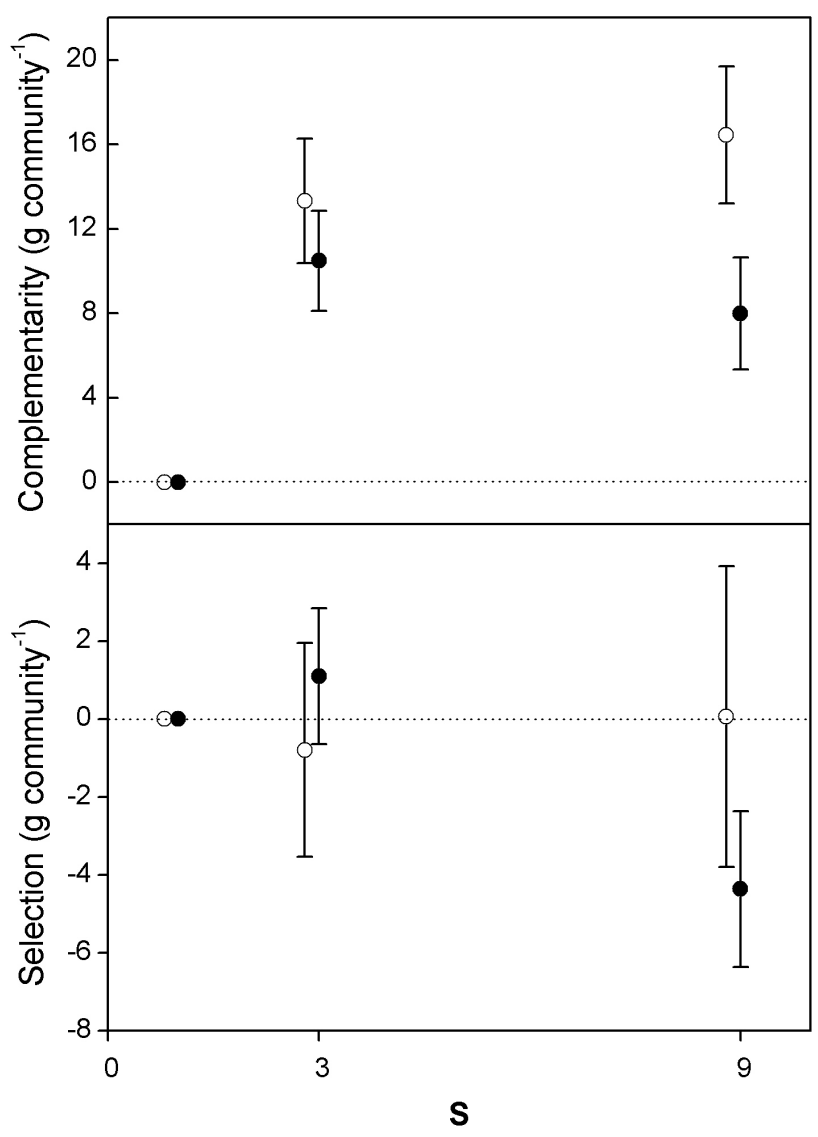

Fig. 2. Average 2003-2005 aboveground ( $>3.5 \mathrm{~cm}$ above the soil surface) biomass overyielding (if $>0$ ) or underyielding (if $<0$ ) due to complementarity or selection, at ambient temperatures (o) and ambient temperatures $+3^{\circ} \mathrm{C}(\bullet)$. Only averages and standard errors for each of the three species richness (S) levels are shown. Symbols are slightly shifted with respect to the $X$-axis for clarity.

communities could be attributed almost exclusively to complementarity effects, with selection effects small and mostly non-significant. As illustrated by Lemmens et al. (2005), this does not imply that all plants were equal competitors, but merely that the net effect of selection on community biomass was close to zero.

It is probable that facilitation through nitrogen fixing by legumes contributed to the positive complementarity effect. Increased $\mathrm{N}$ availability indeed often stimulates plant growth, and legume presence therefore generally increases community productivity (Temperton et al., 2007). Nevertheless, we speculate that the facilitative effects of $\mathrm{N}$ fixing do not explain all of the observed productivity increase in our species-mixtures. Calculations of the evapotranspiration expected in mixtures based on the monoculture ET, showed that the ET actually observed was significantly lower than expected (De Boeck et al., 2006a). This indicates that other mechanisms than merely facilitative effects of legumes were likely involved. Indeed, more complete filling of the three-dimensional space in multi-species com-

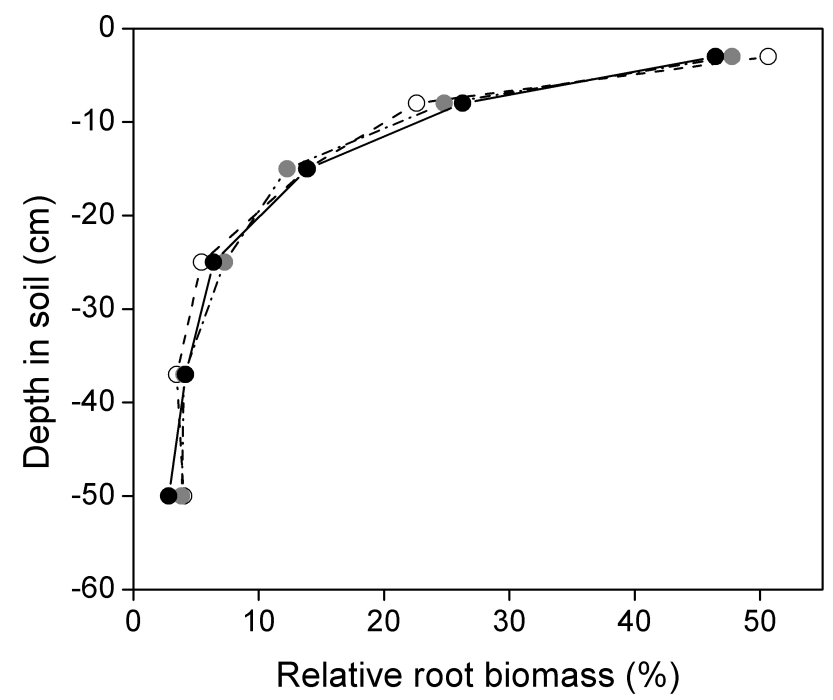

Fig. 3. Average 2003-2005 root profiles for communities of different species richness (S) levels, $S=1$ (o and -) $S=3$ (○ and - -, - --) and $S=9(\bullet$ and -$)$. Data from 48 communities at ambient temperatures and ambient temperatures $+3^{\circ} \mathrm{C}$ were combined. Only average percentages of root biomass in each soil slice are shown (see text for details).

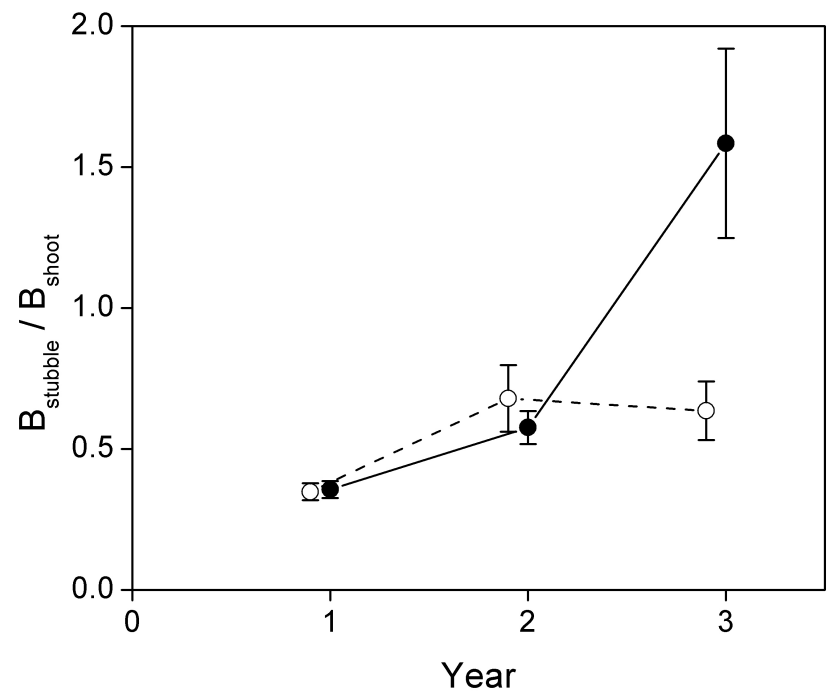

Fig. 4. Ratio of stubble biomass ( $B_{\text {stubble }}$, the biomass $<3.5 \mathrm{~cm}$ above the soil surface) and shoot biomass ( $B_{\text {shoot }}$, the biomass $>3.5 \mathrm{~cm}$ above the soil surface) at ambient temperatures (o and -) and ambient temperatures $+3^{\circ} \mathrm{C}(\bullet$ and -$)$. Data from harvests in October 2003, 2004 and 2005, for all three species richness levels combined. Only averages ( 24 communities) and standard errors are shown. Symbols are slightly shifted with respect to the $X$-axis for clarity.

munities through a less uniform canopy structure compared to monocultures (Cernusca, 1976; Middelboe and Binzer, 2004) not only allows for more light capturing and hence increased photosynthesis, but would at the same time decrease 
the wind speed through the canopy, limiting transpiration increases that accompany higher green biomass (Larcher, 2003). The combination of increased light interception and restrained evapotranspiration through aboveground spatial complementarity could thus have contributed to the observed increased biomass production in mixtures. Another type of complementarity, namely temporal complementarity (Fridley, 2001), is thought to have been negligible in the total complementarity effect as these temperate grassland species have a similar phenology with only limited seasonal activity differences between them.

The fact that monoculture root profiles did not differ significantly between species, suggests that belowground spatial competition in multi-species communities was potentially strong. Such intense interspecific competition between neighbouring plants could cause a relocation of roots to avoid overlap (Mou et al., 1995; Nobel, 1997; Wardle and Peltzer, 2003). Roots seemed more evenly distributed across the soil profile in mixtures, which could confirm this assertion, although differences with monocultures were small (Fig. 3). Soil water measurements suggest that more water was taken up in mixtures (Table 3), which may indicate complementary soil water use in multi-species communities. However, the observed higher water uptake and use in mixtures could also be merely a result of the higher biomass production observed in these communities. Because of the small differences in root overlap between $S$ levels and the limited potential of extra water extraction due to the absence of a water table, we speculate that belowground complementarity for water was limited, and that most of the positive effect of species richness on biomass production was realised through aboveground spatial complementarity (reducing water loss and increasing light capturing), and facilitation through legume presence.

5.1 Are there interactions between the two global changes under consideration?

Biomass data show that the response of plant communities to warming depended on the species richness level. Both above - and belowground data indicate that negative impacts of heating on biomass production were highest in 9-species communities (Fig. 1). This greater discrepancy between both temperature treatments at $\mathrm{S}=9$ was observed in almost all periods, and is supported by similar observations for other measurements such as carbon exchange (De Boeck et al., 2007b). These findings seem in contradiction with the "insurance hypothesis" (Naeem and $\mathrm{Li}, 1997$ ), as the negative impact of warming became more, rather than less, pronounced at the $\mathrm{S}=9$ level.

Such an interaction could emerge if legumes suffered more from warming than other functional groups or if their nitrogen fixing capacity was reduced under elevated temperatures, thereby lowering stimulation of productivity through facilitation. However, no significant shifts in legume vs. other species biomass were observed between temperature treatments (data not shown), and any decline in nitrogen fixing capacity through heating is likely limited (Lilley et al., 2001). Another possible explanation for the observed interaction is the fact that evapotranspiration increased slightly with rising S (Table 3), although less than expected (see earlier), which may have limited productivity through ET-induced drought in multi-species communities (Pfisterer and Schmid, 2002). This would have been more evident in heated communities, where drought was already more pronounced. There was a trend towards lower complementarity under warming, especially at $S=9$ (Fig. 2). Possibly, drought stress limited niche separation in heated multi-species ecosystems as a result of decreased plant vigour (Wardle and Peltzer, 2003), thereby lowering the drought-avoidance potential. In a study on natural ecosystems, Callaway et al. (2002) showed that plantplant interactions are largely positive when abiotic stress is high, whereas competitive interactions prevail under less physically stressful conditions. These findings have more recently been confirmed by Michalet et al. (2006) using a modeling approach. As the grassland species used in the current experiment normally coexist in mild, temperate conditions, it is safe to assume that competition among them is substantial. Exposed to abiotic stress, as was measured primarily under heated conditions, these mainly competitively oriented interactions would then hamper community productivity. If we had performed our experiment on communities in more stressful biomes (where mutualistic relationships prevail), the interaction effect we observed under heating may not have occurred. As this is the first experiment studying effects of climate warming in communities varying in species number, we are unable to compare our findings. A number of questions remain unanswered, such as why the interaction was not detected at $S=3$. It is obvious, however, that studying global changes simultaneously is essential, as the responses to single changes are likely not additive as also evident from other multi-factorial studies (Reich et al., 2001; Wang, 2007).

\section{Conclusions}

Our data suggest that warming could cause a significant nontransient decline of primary production in many temperate grasslands through increased heat and drought stress, and that such a negative impact may not necessarily be alleviated at higher species richness. While single factor studies have provided better mechanistic understanding of the response of plant communities to several predicted global changes, their results can be confounded by co-occurring global changes. Future studies should therefore address multiple global changes simultaneously, which requires largescale and long-term experiments to be able to entangle the multitude of interactions. 
Acknowledgements. This research was funded by the Fund for Scientific Research - Flanders (Belgium) as project "Effects of biodiversity loss and climate warming on carbon sequestration mechanisms in terrestrial ecosystems", contract \# G.0434.03N. H. J. De Boeck holds a grant from the Institute for the Promotion of Innovation through Science and Technology in Flanders (IWTVlaanderen). B. Gielen is a post-doctoral research associate of the Fund for Scientific Research - Flanders. We thank M. Verlinden and M. Fickova for help with biomass harvesting, J. Huyghe and S. Van Dongen for statistical advice, and F. Kockelbergh for technical assistance.

Edited by: A. Arneth

\section{References}

Aerts, R., Cornelissen, J. H. C., and Dorrepaal, E.: Plant performance in a warmer world: General responses of plants from cold, northern biomes and the importance of winter and spring events, Plant Ecol., 182, 65-77, 2006.

Calfapietra, C., Gielen, B., Sabatti, M., De Angelis, P., Miglietta, F., Scarascia-Mugnozza, G., Ceulemans, R.: Do above-ground growth dynamics of poplar change with time under $\mathrm{CO} 2$ enrichment?, New Phytol., 160, 305-318, 2003.

Callaway, R. M., Brooker, R. W., Choler, P., Kikvidze, Z., Lortie, C. J., Michalet, R., Paolini, L., Pugnaire, F. I., Newingham, B., Cook, B. J., and Aschehoug, E. T.: Positive interactions among alpine plants increase with stress, Nature, 417, 844-848, 2002.

Cernusca, A.: Energy exchange within individual layers of a meadow, Oecologia, 23, 141-149, 1976.

Chaves, M. M., Pereira, J. S., Maroco, J., Rodrigues, M. L., Ricardo, C. P. P., Osorio, M. L., Carvalho, I., Faria, T., and Pinheiro, C.: How plants cope with water stress in the field. Photosynthesis and growth, Ann. Bot., 89, 907-916, 2002.

De Boeck, H. J., Lemmens, C. M. H. M., Bossuyt, H., Malchair, S., Carnol, M., Merckx, R., Nijs, I., and Ceulemans, R.: How do climate warming and plant species richness affect water use in experimental grasslands?, Plant Soil, 288, 249-261, 2006a.

De Boeck, H. J., Nijs, I., Lemmens, C. M. H. M., and Ceulemans, R. Underlying effects of spatial aggregation (clumping) in relationships between plant diversity and resource uptake, Oikos, 113, 269-278, 2006b.

De Boeck, H. J, Lemmens, C. M. H. M., Gielen, B., Bossuyt, H., Malchair, S., Carnol, M., Merckx, R., Ceulemans, R., Nijs, I.: Combined effects of climate warming and plant diversity loss on above- and below-ground grassland productivity, Env. Exp. Bot., 60, 95-104, 2007a.

De Boeck, H. J., Lemmens, C. M. H. M., Vicca, S., Van den Berge, J., Van Dongen, S., Janssens, I., Ceulemans, R., Nijs, I.: How do climate warming and species richness affect $\mathrm{CO}_{2}$ fluxes in experimental grasslands?, New Phytol., 175, 512-522, $2007 \mathrm{~b}$.

De Valpine, P., and Harte, J.: Plant responses to experimental warming in a montane meadow, Ecology, 82, 637-648, 2001.

Eatherall, A.: Modelling climate change impacts on ecosystems using linked models and a GIS, Climatic Change, 35, 17-34, 1997.

Edwards, E. J., Benham, D. G., Marland, L. A., and Fitter, A. H.: Root production is determined by radiation flux in a temperate grassland community, Global Change Biol., 10, 209-227, 2004.
Fridley, J. D.: The influence of species diversity on ecosystem productivity: how, where and why?, Oikos, 93, 514-526, 2001.

Gielen, B., De Boeck, H. J., Lemmens, C. M. H. M., Valcke, R., Nijs, I., and Ceulemans, R.: Grassland species will not necessarily benefit from future elevated air temperatures: a chlorophyll fluorescence approach to study autumn physiology, Physiol. Plantarum, 125, 52-63, 2005.

Gielen, B., Naudts, K., D’Haese, D., Lemmens, C. M. H. M., De Boeck, H. J., Biebaut, E., Serneels, R., Valcke, R., Nijs, I., Ceulemans, R.: Effects of climate warming and species richness on photochemistry of grasslands, Physiol. Plantarum, 131, 251-262, 2007.

Gillman, L. N., and Wright, S. D.: The influence of productivity on the species richness of plants: A critical assessment, Ecology, 87, 1234-1243, 2006.

Hector, A., Schmid, B., Beierkuhnlein, C., Caldeira, M. C., Diemer, M., Dimitrakopoulos, P. G., Finn, J. A., Freitas, H., Giller, P. S., Good, J., Harris, R., Högberg, P., Huss-Danell, K., Joshi, J., Jumpponen, A., Körner, C., Leadley, P. W., Loreau, M., Minns, A., Mulder, C. P. H., O’Donovan, G., Otway, S. J., Pereira, J. S., Prinz, A., Read, D. J., Scherer-Lorenzen, M., Schulze, E.-D., Siamantziouras, A.-S. D., Spehn, E. M., Terry, A. C., Troumbis, A. Y., Woodward, F. I., Yachi, S., and Lawton, J. H.: Plant diversity and productivity experiments in European grasslands, Science, 286, 1123-1127, 1999.

Hector, A., Schmid, B., Beierkuhnlein, C., Caldeira, M. C., Diemer, M., Dimitrakopoulos, P. G., Finn, J. A., Freitas, H., Giller, P. S., Good, J., Harris, R., Högberg, P., Huss-Danell, K., Joshi, J., Jumpponen, A., Körner, C., Leadley, P. W., Loreau, M., Minns, A., Mulder, C. P. H., O’Donovan, G., Otway, S. J., Pereira, J. S., Prinz, A., Read, D. J., Scherer-Lorenzen, M., Schulze, E.-D., Siamantziouras, A.-S. D., Spehn, E. M., Terry, A. C., Troumbis, A. Y., Woodward, F. I., Yachi, S., and Lawton, J. H.: No consistent effect of plant diversity on productivity: Response, Science, 289, 1255, 2000.

Hooper, D. U., Chapin, F. S., Ewel, J. J., Hector, A., Inchausti, P., Lavorel, S., Lawton, J. H., Lodge, D. M., Loreau, M., Naeem, S., Schmid, B., Setala, H., Symstad, A. J., Vandermeer, J., and Wardle, D. A.: Effects of biodiversity on ecosystem functioning: A consensus of current knowledge, Ecol. Monogr., 75, 3-35, 2005.

Huston, M. A., Aarssen, L. W., Austin, M. P., Cade, B. S., Fridley, J. D., Garnier, E., Grime, J. P., Hodgson, J., Lauenroth, W. K., Thompson, K., Vandermeer, J. H., and Wardle, D. A.: No consistent effect of plant diversity on productivity, Science, 289, 1255, 2000.

IPCC: Climate Change 2007: The Physical Science Basis. Contribution of Working Group I to the Fourth Assessment Report of the Intergovernmental Panel on Climate Change, edited by Solomon, S., Qin, D., Manning, M., Chen, Z., Marquis, M., Averyt, K. B., Tignor, M., and Miller, H. L., Cambridge University Press, Cambridge, United Kingdom and New York, NY, USA, 2007.

Kahmen, A., Perner, J., and Buchmann, N.: Diversity-dependent productivity in semi-natural grasslands following climate perturbations, Funct. Ecol., 19, 594-601, 2005.

Klein, J. A., Harte, J., and Zhao, X. Q.: Experimental warming causes large and rapid species loss, dampened by simulated grazing, on the Tibetan Plateau, Ecol. Lett., 7, 1170-1179, 2004. 
Larcher W.: Physiological plant ecology, 4th edition, SpringerVerlag, Berlin, 2003.

Lemmens, C. M. H. M., De Boeck, H. J., Gielen, B., Bossuyt, H., Malchair, S., Carnol, M., Merckx, R., Nijs, I., and Ceulemans, R.: End-of-season effects of elevated temperature on ecophysiological processes of grassland species at different species richness levels, Env. Exp. Bot., 56, 245-254, 2006.

Lilley, J. M., Bolger, T. P., Peoples, M. B., and Gifford, R. M.: Nutritive value and the nitrogen dynamics of Trifolium subterraneum and Phalaris aquatica under warmer, high $\mathrm{CO}_{2}$ conditions, New Phytol., 150, 385-395, 2001.

Littell, R. C., Milliken, G. A., Stroup, W. W., Wolfinger, R. D., and Schabenberger, O.: SAS for Mixed Models, Second Edition, SAS Institute Inc., Cary, NC, 2006.

Loreau, M., and Hector, A.: Partitioning selection and complementarity in biodiversity experiments, Nature, 412, 72-76, 2001.

Michalet, R., Brooker, R. W., Cavieres, L. A., Kikvidze, Z., Lortie, C. J., Pugnaire, F. I., Valiente-Banuet, A., and Callaway, R. M.: Do biotic interactions shape both sides of the humped-back model of species richness in plant communities?, Ecol. Lett., 9, 767-773, 2006.

Middelboe, A. L., and Binzer, T.: Importance of canopy structure on photosynthesis in single- and multi-species assemblages of marine macroalgae, Oikos, 107, 422-432, 2004.

Mokany, K., Raison, R. J., and Prokushkin, A. S.: Critical analysis of root: shoot ratios in terrestrial biomes, Global Change Biol., 12, 84-96, 2006.

Mou, P., Jones, R. H., Mitchell, R. J., and Zutter B.: Spatialdistribution of roots in sweetgum and loblolly-pine monocultures and relationships with aboveground biomass and soil nutrients, Funct. Ecol., 9, 689-699, 1995.

Myneni, R. B., Keeling, C. D., Tucker, C. J., Asrar, G., and Namani, R. R.: Increased plant growth in the northern high latitudes from 1981 to 1991, Nature, 386, 698-702, 1997.

Naeem, S., and Li, S.B.: Biodiversity enhances ecosystem reliability, Nature, 390, 507-509, 1997.

Nippert, J. B., Knapp, A. K., and Briggs, J. M.: Intra-annual rainfall variability and grassland productivity: can the past predict the future?, Plant Ecol., 184, 65-74, 2006.

Nobel, P. S.: Root distribution and seasonal production in the northwestern Sonoran desert for a C-3 subshrub, a C-4 bunchgrass, and a CAM leaf succulent, Am. J. Bot., 84, 949-955, 1997.

Norby, R. J., and Luo, Y. Q.: Evaluating ecosystem responses to rising atmospheric $\mathrm{CO}_{2}$ and global warming in a multi-factor world, New Phytol., 162, 281-293, 2004.

Pfisterer, A. B., and Schmid, B.: Diversity-dependent production can decrease the stability of ecosystem functioning, Nature, 416, 84-86, 2002.

Reich, P. B., Knops, J., Tilman, D., Craine, J., Ellsworth, D., Tjoekler, D., Lee, T., Wedin, D., Naeem, S., Bahauddin, D., Hendrey, G., Jose, S., Wrage, K., Goth, J., and Bengtson, W.: Plant diversity enhances ecosystem responses to elevated $\mathrm{CO} 2$ and nitrogen deposition, Nature, 410, 809-812, 2001.

Reichstein, M., Ciais, P., Papale, D., Valentini, R., Running, S., Viovy, N., Cramer, W., Granier, A., Ogée, J., Allard, V., Aubinet, M., Bernhofer, C., Buchmann, N., Carrara, A., Grünwald, T., Heimann, M., Heinesch, B., Knohl, A., Kutsch, W., Loustau, D., Manca, G., Matteucci, G., Miglietta, F., Ourcival, J. M., Pilegaard, K., Pumpanen, J., Rambal, S., Schaphoff, S., Seufert, G.,
Soussana, J.-F., Sanz, M.-J., Vesala, T., and Zhao, M.: Reduction of ecosystem productivity and respiration during the European summer 2003 climate anomaly: a joint flux tower, remote sensing and modelling analysis, Global Change Biol., 13, 634-651, 2007.

Riedo, M., Gyalistras, D., and Fuhrer, J.: Pasture responses to elevated temperature and doubled $\mathrm{CO}_{2}$ concentration: assessing the spatial pattern across an alpine landscape, Climate Research, 17, 19-31, 2001.

Roscher, C., Temperton, V. M., Scherer-Lorenzen, M., Schmitz, M., Schumacher, M., Schmid, B., Buchmann, N., Weisser, W. W., and Schulze, E.-D.: Overyielding in experimental grassland communities - irrespective of species pool or spatial scale, Ecol. Lett., 8, 419-429, 2005.

Rustad, L. E., Campbell, J. L., Marion, G. M., Norby, R. J., Mitchell, M. J., Hartley, A. E., Cornelissen, J. H. C., and Gurevitch, J.: A meta-analysis of the response of soil respiration, net nitrogen mineralization, and aboveground plant growth to experimental ecosystem warming, Oecologia, 126, 543-562, 2001.

Sala, O. E., Chapin, F. S. III, Armesto, J. J., Berlow, E., Bloomfield, J., Dirzo, R., Huber-Sanwald, E., Huenneke, L. F., Jackson, R. B., Kinzig, A., Leemans, R., Lodge, D. M., Mooney, H. A., Oesterheld, M., Le Roy Poff, N., Sykes, M. T., Walker, B. H., Walker, M., and Wall, D. H.: Global bio-diversity scenarios for the year 2100, Science, 287, 1770-1774, 2000.

Saleska, S. R., Harte, J., and Torn, M. S.: The effect of experimental ecosystem warming on $\mathrm{CO}_{2}$ fluxes in a montane meadow, Global Change Biol., 5, 125-141, 1999.

Temperton, V. M., Mwangi, P. M., Scherer-Lorenzen, M., Schmid, B., Buchmann, M.: Positive interactions between nitrogen-fixing legumes and four different neighbouring species in a biodiversity experiment, Oecologia, 151, 190-205, 2007.

Van Peer, L., Nijs, I., Reheul, D., and De Cauwer, B.: Species richness and susceptibility to heat and drought extremes in synthesized grassland ecosystems: compositional vs physiological effects, Funct. Ecol., 18, 769-778, 2004.

van Ruijven, J., and Berendse, F.: Diversity-productivity relationships: Initial effects, long-term patterns, and underlying mechanisms, P. Natl. Acad. Sci. USA, 102, 695-700, 2005.

Walther, G.-R.: Plants in a warmer world, Perspect. Plant Ecol., 6, 169-185, 2003.

Wang, X. Z.: Effects of species richness and elevated carbon dioxide on biomass accumulation: a synthesis using meta-analysis, Oecologia, 152, 595-605, 2007.

Wardle, D. A., and Peltzer, D. A.: Interspecific interactions and biomass allocation among grassland plant species, Oikos, 100, 497-506, 2003.

Weltzin, J. F., Loik, M. E., Schwinning, S., Williams, D. G., Fay, P. A., Haddad, B. M., Harte, J., Huxman, T. E., Knapp, A. K., Lin, G., Pockman, W. T., Shaw, M. R., Small, E. E., Smith, M. D., Smith, S. D., Tissue, D. T., and Zak, J. C.: Assessing the response of terrestrial ecosystems to potential changes in precipitation, Bioscience, 53, 941-952, 2003.

White, T. A., Campbell, B. D., Kemp, P. D., and Hunt, C. L.: Sensitivity of three grassland communities to simulated extreme temperature and rainfall events, Global Change Biol., 6, 671-684, 2000. 